\title{
Mathematical Modeling of Drying in a New Concept of Silo-Dryer-Aerator and the Quality of Soybean Seeds (Glycine max (L.) Merrill)
}

Paulo Carteri Coradi ${ }^{1}$, Ângelo Francisco Calegare Lemes ${ }^{2}$, Jonatas Ibagé Steinhaus ${ }^{2}$, Amanda Müller ${ }^{1}$ and Charline Zaratin Alves ${ }^{2}$

1. Campus Cachoeira do Sul, Federal University of Santa Maria, Street Ernesto Barros, 1345, Cachoeira do Sul/RS, 96506-322, Brazil

2. Campus Chapadão do Sul, Federal University of Mato Grosso do Sul, Rod MS 306, Km 105, PO Box 112, Chapadão do Sul/MS, 79560-000, Brazil

\begin{abstract}
The aim of this study was to model and validate a new concept of a silo-dryer-aerator for the drying of soybean seeds and determine the quality of the seeds in function of the air temperatures in the drying. Soybeans with water contents of $17 \%$ (w.b.) were dried and stored in a silo-dryer-aerator system that was designed with a drying chamber and four independent storage cells in the air drying temperatures at 30,40 and $50{ }^{\circ} \mathrm{C}$ in silo-dryer-aerator. The drying in the air temperature at $30{ }^{\circ} \mathrm{C}$ in the cell $\mathrm{C} 1$ the diffusion approximation model was the one that best fit the data, in the cell $\mathrm{C} 2$ the Newton model prevailed and in the cells $\mathrm{C} 3$ and $\mathrm{C} 4$ the Midilli model. In the drying with air temperature of $40{ }^{\circ} \mathrm{C}$ in the cell $\mathrm{C} 1$ the Page model was the one that better adjusted the data, whereas in the cell $\mathrm{C} 2$ the model of diffusion approximation determined the best fit, while in the cells $\mathrm{C} 3$ and $\mathrm{C} 4$ the Page model obtained better fit. In the drying with air temperature of $50{ }^{\circ} \mathrm{C}$ in the cells $\mathrm{C} 1, \mathrm{C} 2, \mathrm{C} 3$ and $\mathrm{C} 4$ the logarithm model was the one that best represented the fit of the data. The increase in the drying air temperature to $50{ }^{\circ} \mathrm{C}$ decreased the quality of soybeans seeds. In the upper and middle part of the cells there was an increase in electrical conductivity $(140.02 \mu \mathrm{S} / \mathrm{cm} / \mathrm{g}$ ) and germination (53\%) compared with the lower dryer position.
\end{abstract}

Key words: Agricultural engineering, computational dynamics of fluids, post-harvesting, pre-processing, storage.

\section{Introduction}

Soybean is one of the main cereals in the world, and Brazil accounts for $40 \%$ of total grain produced, this cereal is responsible for $27 \%$ of the world market. Brazil is the second largest producer and the largest exporter [1]. Often the soybeans are harvested with water content between $16 \%$ and $18 \%$, making it necessary to subject it to drying, in order to prevent enzymatic reactions and the development of fungi and microorganisms producing hydrolytic enzymes with lipases, which leads to an increase of

Corresponding author: Paulo Carteri Coradi, professor, research fields: agricultural engineering, post-harvesting, drying, storage, processing and quality of agricultural products. free fatty acids, which affect the quality of the seeds [2].

The drying process aims to partial removal of water from the seeds, through the simultaneous transfer of heat from the air and seeds and mass flow through the water vapor, the beans into the air. The information about the behavior of the phenomenon of heat and mass transfer between the biological material and the element of drying are essential for design, operation simulations of drying, dryers and seed quality systems. A reduction in the water content of the seeds diminishes their biological activity and microbiological, physical and chemical changes during storage [3-6].

Artificial drying methods are used according to the 
variation in the heat supply, which is distributed by the air flow, which the air imparts heat to the seed mass in a continuous, intermittent or stationary manner [7-9]. The studies have been conducted for developing new dryers and improving the existing ones to obtain a higher yield and maintain the quality of the agricultural products, which the main factors involved in this improvement are the temperature and air flow controls, the velocity and pressure of the heated air, and the movement and uniformity of the water content of the product $[2,10]$.

To evaluate the drying systems, their dimensioning, optimization and determining the feasibility of its commercial application can be made by mathematical simulation, whose principle is based on the successive thin layers drying the product, using a mathematical model that is satisfactorily water loss [3, 11-13]. Drying of hygroscopic products is described by theory, empirical and semi theoretical methods. In theoretical methods usually consider the external conditions under which the operation occurs as well as the internal mechanisms of energy transfer and mass and its effects.

Considering that drying systems have been the main bottleneck in the flow of soybeans in warehouses, due to the high water content, the drying time of the seeds and the high costs with drying equipment, it is necessary sizing systems with drying and drying with aeration during storage. Currently, the methods used for dry-aeration are not efficient, causing problems with moisture transfer and heating of the mass of stored seeds. These problems are caused by the mixing of the lots of seeds in the silos with heterogeneous moisture and also by the aeration conditions which are inferred by the relative humidity of the ambient air and temperatures. Thus, the aim of this study was to model and validate a new concept of a silo-dryer-aerator for the drying of soybean seeds and determine the quality of the seeds in function of the air temperatures in the drying.

\section{Materials and Methods}

The municipality of Chapadão do Sul is located in the south of the center-west region of Brazil, in the north of Mato Grosso do Sul (microregion of Cassilândia). The designed silo-dryer-storage system was composed of a chamber with four independent drying-storage cells that were arranged inside to separate the seeds in bands of water content, impurities or seed size, or even different species, aiming at the increase of the yield and the high quality of the seeds in drying-storage (Fig. 1). The silo-dryer-aerator grains prototype is shown in Fig. 2. It was built with 14-inch, circular and raised metal plates containing a drying-storage chamber (Fig. 2, point e) of $2 \mathrm{~m}$ height and $1 \mathrm{~m}$ in diameter, with a variable static capacity according to the seed type (average of $164 \mathrm{~kg}$ ). The floor was scaled with $10 \%$ of its total perforated area. In the interior, four mobile drying-storage cells were built for storing the seed mass during drying-storage, each measuring $1.5 \mathrm{~m}$ in height and $0.2 \mathrm{~m}$ in diameter, constructed of 12-inch metal plates, with walls of holes $2 \mathrm{~mm}$ in diameter and open at the top.

The silo-dryer plenum (Fig. 2, point d), with the function of reducing the drying air velocity or aeration was arranged below the drying-storage chamber, with a diameter of $1.5 \mathrm{~m}$ and a height of $0.30 \mathrm{~m}$. In the center of the plenum, one of the electrical resistors (only for drying) with 4,000 watts of power was installed. The other electric resistance (drying only) of the same power was fixed in a plenum (Fig. 2, points $\mathrm{b}$ and $\mathrm{c}$ ) front compartment, $1.5 \mathrm{~m}$ long and $0.5 \mathrm{~m}$ high. A centrifugal fan of straight blades, of flow of $20 \mathrm{~m}^{3} / \mathrm{min}$ and static pressure of $392 \mathrm{~Pa}$, power of 0.5 $\mathrm{cv}$, tension of $220 / 380 \mathrm{~V}$, rotation of $1,750 \mathrm{rpm}$, single-phase, structure of carbon steel, rotor in aluminum alloy, noise $90 \mathrm{DBA}$, weight of $35 \mathrm{~kg}$ was coupled to an air expansion chamber (Fig. 2, point a) $1.5 \mathrm{~m}$ long and $0.5 \mathrm{~m}$ high interconnected with the silo-dryer-aerator body (Fig. 2). 

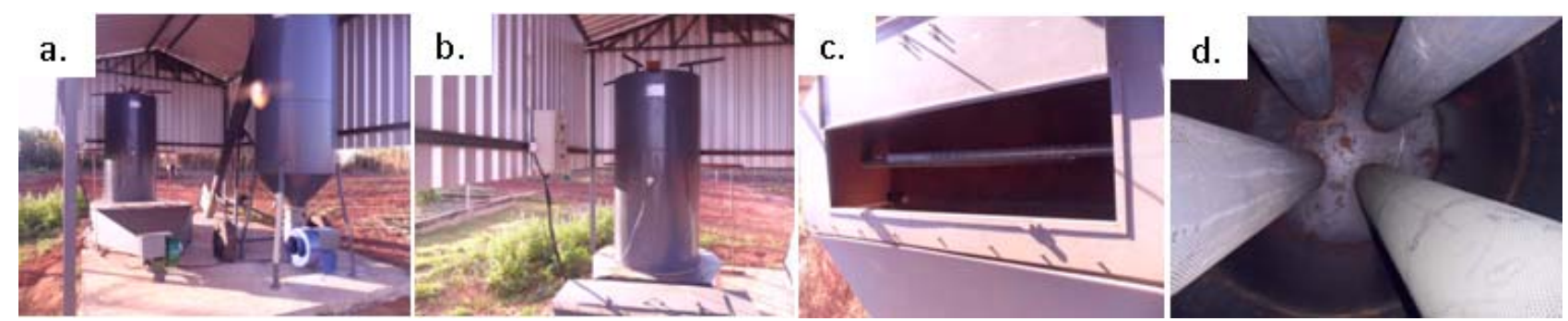

Fig. 1 Seeds drying and storage unit (a), automated drying system (b), heating system with electric resistances (c) and cells inside the drying chamber (d).

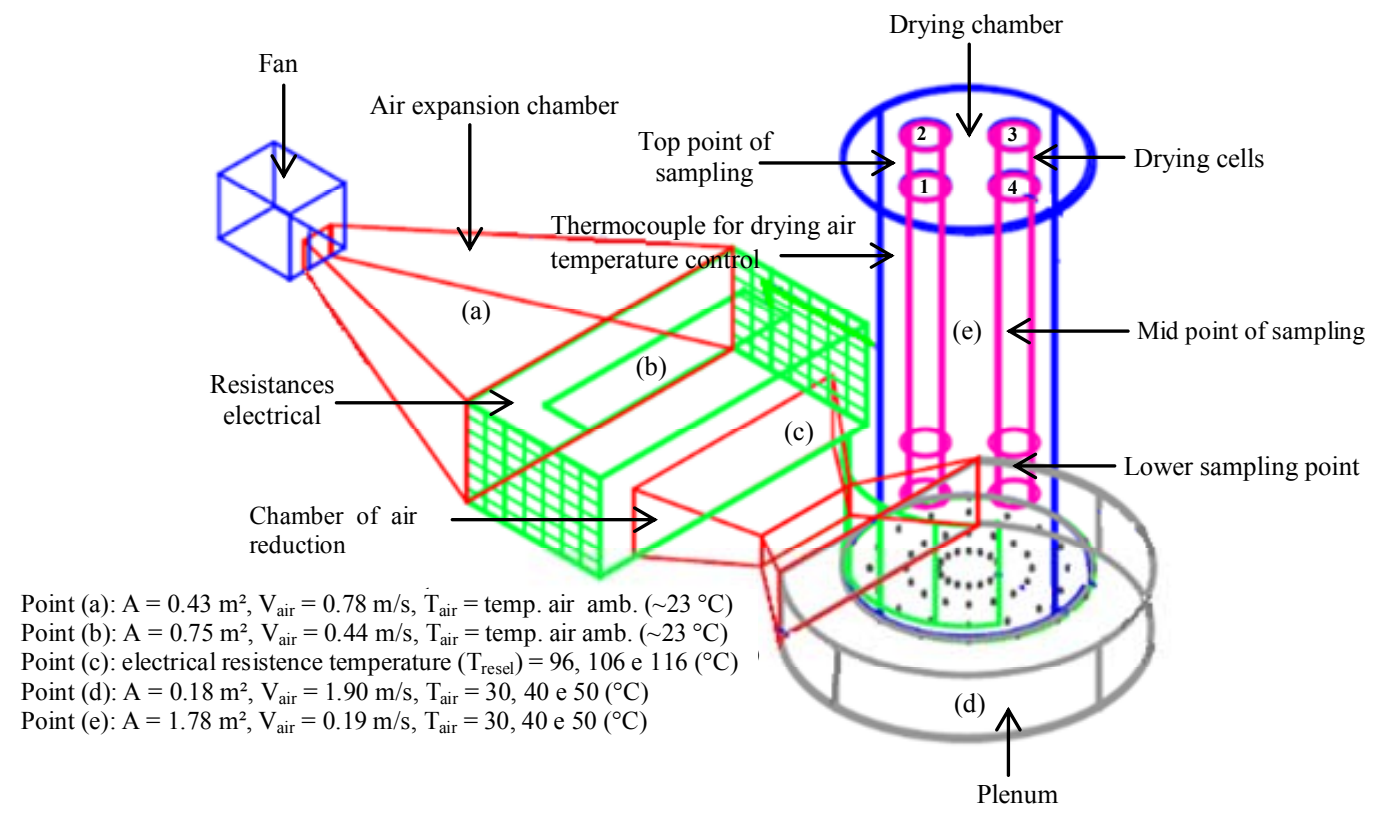

Fig. 2 Experimental prototype silo-dryer-aerator seeds.

The instrumentation of the silo-dryer-aerator system was performed with the control of the air temperature directly in the electrical resistances, through an external controller with dimensions of $500 \mathrm{~mm} \times 400 \mathrm{~mm} \times 250$ $\mathrm{mm}$, channels with an open cut out for cable housing, circuit breaker protection for $10 \mathrm{~A}$ control and $40 \mathrm{~A}$ power, 24 vec switching power supply for solid state relay drive, $40 \mathrm{~A}$ three phase solid state relay with heat sink, N1040-PR temperature controller for system control, input and output terminal strip of control cables and force. According to the airflow and heating of the silo-dryer, the variations in the speed and temperature of the drying air were obtained. The storage silo was constructed of 14-inch metal sheets. For the aeration and cooling of the seeds mass in the storage-aerator silo, a centrifugal fan with straight blades, a flow rate of 45 $\mathrm{m}^{3} / \mathrm{m}$, static pressure of $1,862 \mathrm{~Pa}$, voltage of $220 / 380 \mathrm{~V}$, radial rotor, power of $3 \mathrm{cv}$, rotation of $3,500 \mathrm{rpm}$, noise of $90 \mathrm{DBA}$, weight of $50 \mathrm{~kg}$, single-phase, structure of carbon steel, and cast aluminum rotor. The silo-dryer-aerator seeds were moved to the silo-storage-aerator by a $4 \mathrm{~m}$ long, $0.30 \mathrm{~m}$ diameter helical screw made of 14-inch metal sheets. It was made with a single-phase motor, $220 \mathrm{~V}, 3$ HP power, with a transmission via a set of pulleys and belt.

To assess the fluid from the heated and cooling air in the silo-dryer-aerator used was a computational tool called computational fluid dynamics (CFD) [13]. For the simulation was taken into account the constructive characteristics of the silo-dryer-aerator, the heating 
and cooling system of the air, environmental variables controlled, initial and boundary conditions, the physical parameters of air. For the simulation a mathematical model of the air convection inside the dryer was build taking into account the type of air flow, the thermophysical properties of the fluid, the viscous dissipation in the flow and the pressure term in the energy equation, the surfaces of dryer. The problem in question was characterized as a forced convection air flow. The initial condition of average ambient temperature was $23^{\circ} \mathrm{C}$.

For the boundary conditions was considered a temperature of 30,40 and $50{ }^{\circ} \mathrm{C}$ on the wall below the entrance of the heated air, south side geometry and heat flow equal to zero, the symmetry conditions to the same side. On the east side, west and north were considered as insulated wall and heat flow equal to zero. Whereas the geometry of the system is presented with large, interfering with the convergence of cells convective heating air inside the shed, admisionalization of values became an alternative necessary for the simulation. For this, it was considered the following, for length (L) of the section (dryer) $=1$. For the simulation of air settled the following custom physical parameters: $\rho=1 \mathrm{~kg} / \mathrm{m}^{3} ; c_{p}$ $=0.72 \mathrm{~J} / \mathrm{kg} /{ }^{\circ} \mathrm{C} ; k=0.072 \mathrm{~W} / \mathrm{m} /{ }^{\circ} \mathrm{C} ; \mu=0.1 \mathrm{~kg} / \mathrm{m} / \mathrm{s} ; \beta=$ $13.88(1 / \mathrm{k}) ; q=0 \mathrm{~W} / \mathrm{m}^{3} ; g=10 \mathrm{~m} / \mathrm{s}^{2}$, wherein $\rho$ : specific mass, $c_{p}$ : specific heat, $k$ : electric conductivity, $\mu$ : viscosity, $q$ : heat flow and $\beta$ : thermal expansion coefficient. The volumetric expansion coefficient was calculated according to the number of Rayleigh $\left(R_{a, L}\right)$, by Eq. (1), while its convergence occurred when 1,708 $<R_{a, L}<5 \times 10^{5}$. Thus, it adopted $R_{a, L}=10^{4}$, resulting in $\beta=13.88(1 / \mathrm{k})$, allowing the convergence and better distribution of temperature, pressure, speed and heat flow:

$$
R_{a, L}=\frac{g \beta\left(T_{1}-T_{2}\right) L^{3}}{\alpha \mu}
$$

where $T_{1}$ : initial temperature, $T_{2}$ : final temperature, $\alpha$ : coefficient of thermal diffusivity, $L$ : section length and $R_{a, L}$ : Rayleigh. The coefficient of thermal diffusivity was determined by Eq. (2):

$$
\alpha=\frac{k}{\rho c_{p}}
$$

Fig. 3 shows the flow of the convective air and the distribution of the heat inside the dryer. Eqs. (3-5) characterize the flow:

Continuity equation:

$$
\frac{\partial u}{\partial x}+\frac{\partial v}{\partial y}=0
$$

Equation of the momentum in the $x$-direction:

$$
\begin{aligned}
& \frac{\partial u}{\partial t}+u \frac{\partial u}{\partial x}+v \frac{\partial u}{\partial y}=\frac{-1}{\rho} \frac{\partial p}{\partial x}+ \\
& v\left(\frac{\partial^{2} u}{\partial x^{2}}+\frac{\partial^{2} u}{\partial y^{2}}\right)+\beta\left(T-T^{r}\right) \vec{g} \cdot \vec{i}
\end{aligned}
$$

Equation of the amount of movement in the $y$-direction:

$$
\begin{aligned}
& \frac{\partial v}{\partial t}+u \frac{\partial v}{\partial x}+v \frac{\partial v}{\partial y}=\frac{-1}{\rho} \frac{\partial p}{\partial y}+ \\
& v\left(\frac{\partial^{2} v}{\partial x^{2}}+\frac{\partial^{2} v}{\partial y^{2}}\right)+\beta\left(T-T^{r}\right) \vec{g} \cdot \vec{j}
\end{aligned}
$$

where $u$ is the velocity in the direction $(x)(\mathrm{m} / \mathrm{s}), v$ is the velocity in the direction $(y)(\mathrm{m} / \mathrm{s}), x$ is the horizontal coordinate $(\mathrm{m}), y$ is the vertical coordinate $(\mathrm{m}), p$ is a specific mass $\left(\mathrm{kg} / \mathrm{m}^{3}\right), \delta$ is the gradient, $\beta$ is the volumetric expansion coefficient, $T$ is the temperature $\left({ }^{\circ} \mathrm{C}\right), i$ is the unit vector in the $x$-direction, $J$ is the unit vector in the $y$-direction. Eq. (6) represents the conservation of energy in the system:

$$
\frac{\partial T}{\partial t}+u \frac{\partial T}{\partial x}+v \frac{\partial T}{\partial y}=\alpha\left(\frac{\partial^{2 T}}{\partial x^{2}}+\frac{\partial^{2 T}}{\partial y^{2}}\right)
$$

where $\alpha$ is the thermal diffusivity $\left(\mathrm{m}^{2} / \mathrm{s}\right)$.

The silo-dryer-aerator fixed bed, with a capacity of $164 \mathrm{~kg}$ of soybean was loaded from the top, then the air ventilation system and the heating system with electric resistances was triggered through an external controller for the temperature control of the drying air at 30,40 and $50{ }^{\circ} \mathrm{C}$. The seeds lots were individually dried for each air temperature. During the drying, the temperature conditions of the seeds mass were monitored with the help of mercury thermometers in the four drying cells. At each interval of $1 \mathrm{~h}$, the seeds 
Table 1 Semi-empirical and empirical equations for mathematical modeling of the soybean grains.

\begin{tabular}{lll}
\hline Equations & Models & $(7)$ \\
\hline$R U=\exp (-k t)$ & Newton & $(8)$ \\
$R U=\exp \left(-k t^{n}\right)$ & Page & $(9)$ \\
$R U=a \exp (-k t)$ & Henderson and Pabis & $(10)$ \\
$R U=a \exp (-k t)+c$ & Logarithmic & $(11)$ \\
$R U=a \exp \left(-k_{o} t\right)+b \exp \left(-k_{1} t\right)$ & Two terms & $(12)$ \\
$R U=1+a t+b t^{2}$ & Wang and Singh & $(13)$ \\
$R U=a \exp (-k t)+b \exp \left(-k_{o} t\right)+c \exp \left(-k_{1} t\right)$ & Henderson and Pabis modified & $(14)$ \\
$R U=a \exp \left(-k t^{n}\right)+b t$ & Midilli & $(15)$ \\
$R U=a \exp (-k t)+(1-a) \exp (-k b t)$ & Diffusion approximation
\end{tabular}

$R U$ : moisture ratio (dimensionless); $t$ : drying time (h); $k, k_{0}, k_{1}$ : drying constant $\left(\mathrm{h}^{-1}\right) ; a, b, c$ : model coefficients; $n$ : number of terms of the equation; $D$ : diffusion coefficient $\left(\mathrm{m}^{2} / \mathrm{s}\right) ; L$ : product thickness $(\mathrm{m})$.

were sampled throughout the mass profile of the four drying cells, using a grain-water sampler to determine the water content. The water content of the samples was determined via the gravimetric method [14]. The drying curves were fitted to the experimental data using different semi-empirical and empirical equations discriminated in Table 1.

To adjust the mathematical models of analysis drying grains were performed nonlinear regression, Quasi-Newton method, using the computer program Statistica $7.0^{\mathbb{R}}$. To check the degree of fit of each model was considered the significance of the regression coefficient by $t$-test, adopting the $5 \%$ level of probability, the magnitude of the coefficient of determination $\left(R^{2}\right)$, the mean relative error values $(P)$ and the average estimated error (SE) and verified the behavior of distribution of residuals. The relative average error and the average error estimated for each model were calculated according to the following expressions, respectively:

$$
\begin{aligned}
& P=\frac{100}{n} \sum \frac{|Y-\hat{Y}|}{Y} \\
& S E=\sqrt{\frac{\sum(Y-\hat{Y})^{2}}{G L R}}
\end{aligned}
$$

where $Y$ : experimentally observed value; $\hat{Y}$ : value calculated by the model; $n$ : number of experimental observations; GLR: degrees of freedom of the model.

At the end of the drying, a top, middle and lower sample of the four cells was collected and mixed for a single quality assessment sample.

The water content (\% w.b.) was determined by the difference between initial and final grain masses, submitted to forced drying at $105 \pm 1{ }^{\circ} \mathrm{C}$ for $24 \mathrm{~h}$, with three replicates of $15 \mathrm{~g}$ [14]. The electrical conductivity test was conducted in soybean seeds [15]. The germination test was conducted with four subsamples of 50 grains for each treatment, placed in rolls of "Germitest" paper towels, and packed in "Mangelsdorf" type germinator at a constant temperature of $25 \pm 2{ }^{\circ} \mathrm{C}$. Grain germination results were analyzed on the 5th and 8th days [14]. The results were submitted to statistical analysis by the program SISVAR.

\section{Results and Discussion}

Fig. 3 is simulation (temperature, velocity, pressure, heat flow and power line) of the heated air inside the grain dryer to temperatures at 30,40 and $50^{\circ} \mathrm{C}$. It was found in the parameters evaluated that there was a uniform distribution of the heated air from the bottom of the drying chamber, in defined layers and heating air circulation inside the dryer. The air speed parameter had similar changes for all temperatures with initial values in the air inlet $0.65 \mathrm{~m} / \mathrm{s}$ to $0.00 \mathrm{~m} / \mathrm{s}$ the air outlet of the drying chamber. On average the recommended air velocity in the seed mass at the drying process should be $0.35 \mathrm{~m} / \mathrm{s}$ [15]. The increased speed can cause cracks and breaks in the grains [15]. 

Soybean Seeds (Glycine max (L.) Merrill)

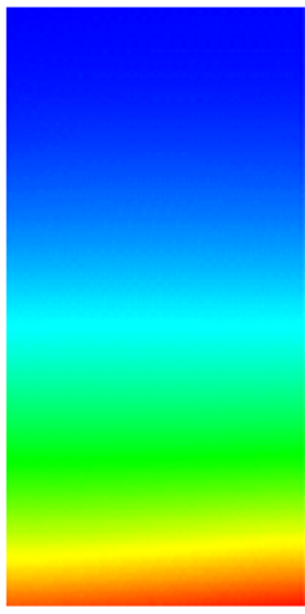

a) Temperature
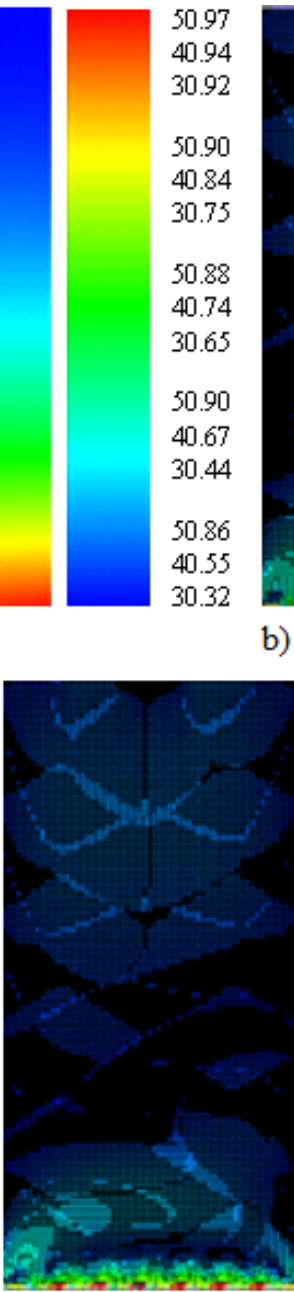

d) Heat flow

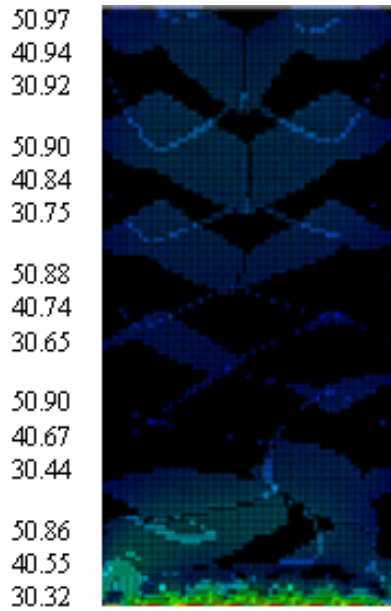

b) Velocity

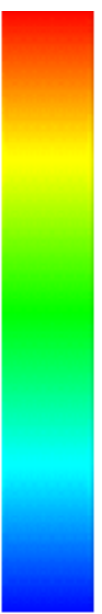

0.65

0.32

0.16

0.00

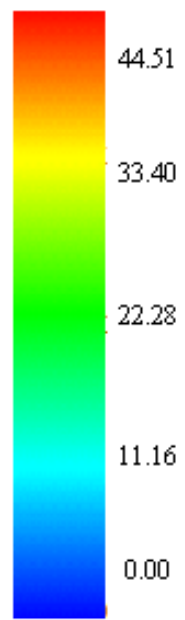

0.00

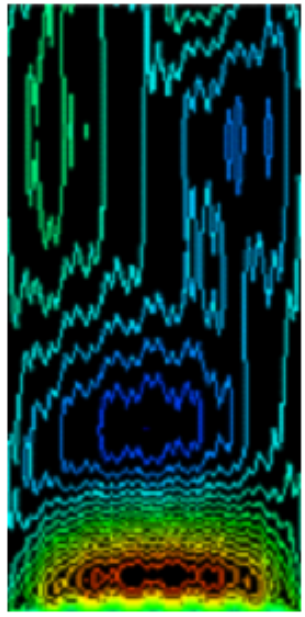

e) Current line
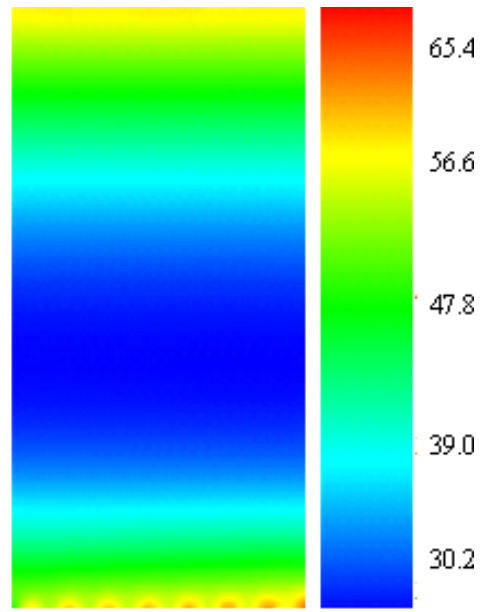

c) Pressure

Fig. 3 Simulations of the heated air in the silo-dryer-aerator represented by temperature $\left({ }^{\circ} \mathrm{C}\right)$, velocity $(\mathrm{m} / \mathrm{s})$, pressure $(\mathrm{Pa})$, heat flow $\left(\mathrm{m}^{3} / \mathrm{min} / \mathrm{m}^{2}\right.$ in the dryer) and current line (m).

The way it processes the drying fixed layer originates temperature gradients and moisture in the grain mass [16]. In the stationary dryer with radial air distribution under temperature of $40{ }^{\circ} \mathrm{C}$, did not observe differences between the nearest grain temperatures to the central tube and away [16]. In contrast, soybean, found gradient to $15{ }^{\circ} \mathrm{C}$ under similar dryers.

The water content gradient between seeds differently spaced in relation to the air inlet area depends on the relative humidity, temperature, air flow, the water content of the pasta thickness and the water transfer capability of grain into the air. This gradient is reduced with decreases in temperature and thickness of the seed weight and increased flow of air. In the more distant sections of the air inlet may be an increase of the seed moisture content as a result of condensation caused by the passage of humid air in layers over low temperature $[17,18]$. The relationship between the volume of air that passes through the product mass, the resistance to passage of air and the height of the product layer above the distribution system, are important in the design, selection and operation of the air handling equipment. In the results of dynamic air pressure inside the dryer, the variation of pressure was $35.19 \mathrm{~Pa}$ and decreasing air pressure in the middle third of the equipment was increased and the upper third, approaching the initial 
pressure observed in the first third of the equipment. It was observed that there was no difference between the heating temperature of the air, and the air pressure in the dryer output was higher (65.46 Pa), while the middle third of the drying chamber air pressure was lower (30.27 Pa).

The distribution of air current lines was above the entrance of the dryer. However, the air current lines showed similar behavior and identical values for all tested temperatures. The larger air currents were obtained in the upper third of the dryer, the left side of the machine. A reduction of the air flow was observed in the middle third of the equipment. For the heating of the air temperature $30{ }^{\circ} \mathrm{C}$ current lines were higher $(0.03 \mathrm{~m} / \mathrm{s}$ to $0.00 \mathrm{~m} / \mathrm{s})$ while the other temperatures was $0.02 \mathrm{~m} / \mathrm{s}$ to $0.00 \mathrm{~m} / \mathrm{s}$.

The air flow was $44.51 \mathrm{~m} / 3 \mathrm{~min} / \mathrm{m}^{2}$ in the dryer. It was found that the heat flow in the dryer was higher in the inlet of the drying chamber, decreasing along the way, but at different initial amounts for each temperature [19]. The wetter seeds are more susceptible to thermal damage, for which reason suggested that the higher the water content, the lower temperature should be employed. However, the surface water can be removed under high air temperature, since the evaporation process removes sufficient heat, not changing the temperature of the beans [20]. Below 30\% water, however, the amount of water is less available for evaporation. The air flow should be sufficient not to become saturated before leaving the mass of seeds can be increased while being able to absorb all the water released by the seeds [21, 22].

From this point the water migration from the interior to the surface of each seed, it becomes the main factor affecting the drying rate. The seed mass temperatures ranging between $40.5{ }^{\circ} \mathrm{C}$ and $43.3{ }^{\circ} \mathrm{C}$ are considered to be maximum, and most of them can be generated physical or chemical damage [23]. However, the difference between the temperature of the supply air and the seed mass depends on the type of dryer, the botanical species concerned and the movement of air resistance, making it necessary to know the heat behavior in every type of dryer and in each species.

The drying curves, observed in Figs. 4a-4c, represent the reduction of water contents of the seeds from $17 \%$ to $11.5 \%$ (w.b.) at $30{ }^{\circ} \mathrm{C}$, from $17 \%$ to $10.3 \%$ (w.b.) at $40{ }^{\circ} \mathrm{C}$ and from $17 \%$ to $10.5 \%$ (w.b.) at $50{ }^{\circ} \mathrm{C}$. Cell 1 showed the greatest reduction (with respect to time) in the water content of the seeds at $30{ }^{\circ} \mathrm{C}$ and $40{ }^{\circ} \mathrm{C}$, until the end of the drying. The reduction in the water content of the seeds at $50{ }^{\circ} \mathrm{C}$ was similar for all four dryer cells. Moreover, the drying time was $2 \mathrm{~h}$ less $(8 \mathrm{~h})$ at $50{ }^{\circ} \mathrm{C}$ compared with the $10 \mathrm{~h}$ at $30^{\circ} \mathrm{C}$ and $40{ }^{\circ} \mathrm{C}$.

This behavior is typical of several agricultural products and has been observed by several researchers studying numerous agricultural products [24-26]. Figs. 4a-4d respectively show that the drying cells 1, 2, 3 and 4 exhibited similar behaviors at the same temperatures and drying at $50{ }^{\circ} \mathrm{C}$ reduced the drying time to $8 \mathrm{~h}$ in all of the four cells. In addition, in the first $2 \mathrm{~h}$ the drying curve was more pronounced, showing a greater reduction of water contents in the seeds with the increase of drying air temperature.

The reduction of water in the grain during the drying period is governed by the water reduction rate until it becomes stable because the reduction in free water slows the migration of water from the interior to the surface of the grain $[19,27]$. This behavior indicates that diffusion is the largest probable physical mechanism, which governs the movement of water in the thin layers [16, 28]. Moreover, the drying air temperature is the main indication for accelerating the movement of water in the thin layers. Thus, regardless of the cell, there was a significant reduction in water content at the upper sampling point compared with the middle and lower points of the cells. Moreover, the difference observed was greater with the increase in temperature of the drying air indicating that the superior points had a higher drying rate, which caused the highest reduction in the grain water content at all drying temperatures and cells. As seen in Table 2, the 

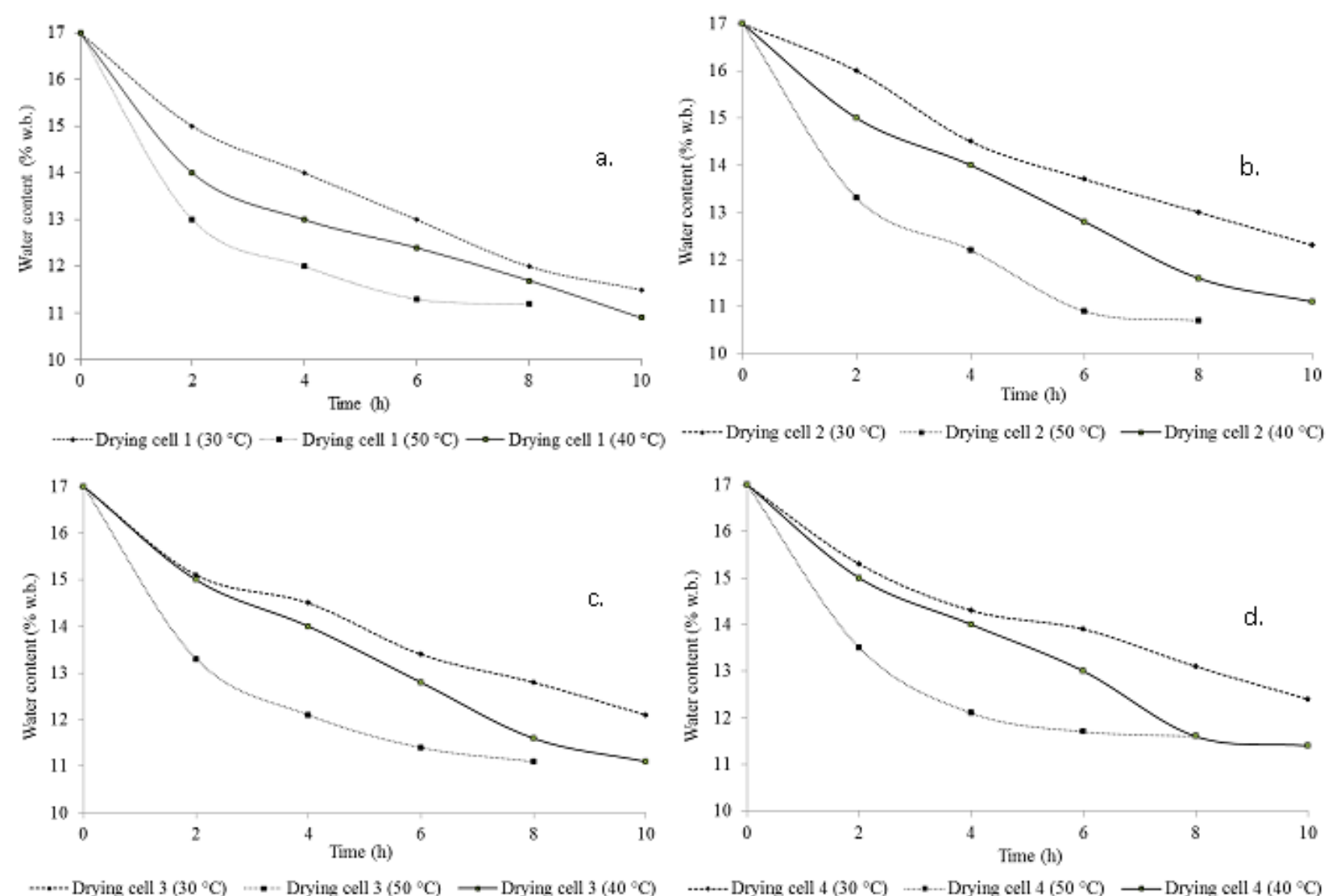

...... Drying cell $3\left(30^{\circ} \mathrm{C}\right) \cdots$ Drying cell $3\left(50^{\circ} \mathrm{C}\right) \quad$ - Drying cell $3\left(40^{\circ} \mathrm{C}\right)$

-... Drying cell $4\left(30^{\circ} \mathrm{C}\right) \quad \rightarrow$ Drying cell $4\left(50^{\circ} \mathrm{C}\right) \rightarrow$ Drying cell $4\left(40^{\circ} \mathrm{C}\right)$

Fig. 4 Curves drying soybeans versus temperature, (a) drying cell 1, (b) drying cell 2, (c) drying cell 3 and (d) drying cell 4.

coefficients " $k$ ", " $a$ " and " $b$ " represent the effects of external drying conditions, the constant " $k$ ", "a" and " $b$ " can be used as an approach to characterize the effect of temperature related to the effective diffusivity in the drying process period and the descending liquid diffusion controlling the process [29]; while the constant " $n$ " reflects the internal strength of the product drying.

The coefficient of determination is a good parameter to check the fit of nonlinear models and typically has higher values for the models that best fit the experimental data (Table 3). Thus, it was observed that for most treatments, the coefficients of determination $R^{2}$ were above $99 \%$, indicating a satisfactory representation of the phenomenon under study [30, 31] (Table 3).

For the drying air temperature of $30^{\circ} \mathrm{C}$, in the cell $\mathrm{C} 1$ the diffusion approximation model was the one that best fit the data, in the cell $\mathrm{C} 2$ the Newton model prevailed and in the cells $\mathrm{C} 3$ and $\mathrm{C} 4$ the Midilli model. In the drying with air temperature of $40{ }^{\circ} \mathrm{C}$, in the cell $\mathrm{C} 1$ the Page model was the one that better adjusted the data, whereas in the cell $\mathrm{C} 2$ the model of diffusion approximation determined the best fit, while in the cells $\mathrm{C} 3$ and $\mathrm{C} 4$ the Page model obtained better fit. In the drying with air temperature of $50{ }^{\circ} \mathrm{C}$, in the cells $\mathrm{C} 1, \mathrm{C} 2, \mathrm{C} 3$ and $\mathrm{C} 4$ the Logarithm model was the one that best represented the fit of the data (Figs. 5-7).

It was observed that the drying coefficients " $k$ ", " $a$ " and " $b$ " increased with increasing temperature, while the constant " $n$ " decreased with increasing temperature. Table 4 shows the results of drying the seeds at air temperatures of 30,40 and $50{ }^{\circ} \mathrm{C}$, with a relative humidity of the ambient air varying from $70.5 \%$ to $45.5 \%$. The temperature in the seed mass ranged from $26.9^{\circ} \mathrm{C}$ to $33.5^{\circ} \mathrm{C}$; the exhaust air temperature 

Soybean Seeds (Glycine max (L.) Merrill)

Table 2 Parameter values estimated for mathematical models of drying at 30,40 and $50{ }^{\circ} \mathrm{C}$ of soybean seeds.

\begin{tabular}{|c|c|c|c|c|}
\hline Mathematical models & $\mathrm{T}\left({ }^{\circ} \mathrm{C}\right)$ & $k$ & & \\
\hline & $30 \mathrm{C} 1$ & 0.0020 & & \\
\hline & $30 \mathrm{C} 2$ & 0.0014 & & \\
\hline & $30 \mathrm{C} 3$ & 0.0016 & & \\
\hline & $30 \mathrm{C} 4$ & 0.0015 & & \\
\hline & $40 \mathrm{C} 1$ & 0.0026 & & \\
\hline & $40 \mathrm{C} 2$ & 0.0021 & & \\
\hline Newton & $40 \mathrm{C} 3$ & 0.0022 & & \\
\hline & $40 \mathrm{C} 4$ & 0.0021 & & \\
\hline & $50 \mathrm{C} 1$ & 0.0039 & & \\
\hline & $50 \mathrm{C} 2$ & 0.0040 & & \\
\hline & $50 \mathrm{C} 3$ & 0.0037 & & \\
\hline & $50 \mathrm{C} 4$ & 0.0034 & & \\
\hline & $\mathrm{T}\left({ }^{\circ} \mathrm{C}\right)$ & $k$ & $n$ & \\
\hline & $30 \mathrm{C} 1$ & 0.0040 & 0.8880 & \\
\hline & $30 \mathrm{C} 2$ & 0.0022 & 0.9230 & \\
\hline & $30 \mathrm{C} 3$ & 0.0051 & 0.8144 & \\
\hline & $30 \mathrm{C} 4$ & 0.0062 & 0.7662 & \\
\hline & $40 \mathrm{C} 1$ & 0.0212 & 0.6455 & \\
\hline Page & $40 \mathrm{C} 2$ & 0.0005 & 1.2178 & \\
\hline Page & $40 \mathrm{C} 3$ & 0.0023 & 0.9931 & \\
\hline & $40 \mathrm{C} 4$ & 0.0030 & 0.9436 & \\
\hline & $50 \mathrm{C} 1$ & 0.0837 & 0.4524 & \\
\hline & $50 \mathrm{C} 2$ & 0.0254 & 0.6712 & \\
\hline & $50 \mathrm{C} 3$ & 0.0491 & 0.5418 & \\
\hline & $50 \mathrm{C} 4$ & 0.0665 & 0.4726 & \\
\hline & $\mathrm{T}\left({ }^{\circ} \mathrm{C}\right)$ & $a$ & $k$ & \\
\hline & $30 \mathrm{C} 1$ & 0.9818 & 0.0020 & \\
\hline & $30 \mathrm{C} 2$ & 0.9982 & 0.0014 & \\
\hline & $30 \mathrm{C} 3$ & 0.9714 & 0.0016 & \\
\hline & $30 \mathrm{C} 4$ & 0.9667 & 0.0014 & \\
\hline & $40 \mathrm{C} 1$ & 0.9416 & 0.0024 & \\
\hline & $40 \mathrm{C} 2$ & 1.0526 & 0.0022 & \\
\hline Henderson and Pabis & $40 \mathrm{C} 3$ & 0.9959 & 0.0022 & \\
\hline & $40 \mathrm{C} 4$ & 0.9895 & 0.0021 & \\
\hline & $50 \mathrm{C} 1$ & 0.9387 & 0.0036 & \\
\hline & $50 \mathrm{C} 2$ & 0.9651 & 0.0039 & \\
\hline & $50 \mathrm{C} 3$ & 0.9486 & 0.0035 & \\
\hline & $50 \mathrm{C} 4$ & 0.9385 & 0.0031 & \\
\hline & $\mathrm{T}\left({ }^{\circ} \mathrm{C}\right)$ & $a$ & $k$ & $c$ \\
\hline & $30 \mathrm{C} 1$ & 0.8971 & 0.0022 & 0.0868 \\
\hline & $30 \mathrm{C} 2$ & 0.7497 & 0.0023 & 0.2659 \\
\hline & $30 \mathrm{C} 3$ & 0.7820 & 0.0023 & 0.2039 \\
\hline & $30 \mathrm{C} 4$ & 0.6975 & 0.0026 & 0.2904 \\
\hline & $40 \mathrm{C} 1$ & 0.7487 & 0.0047 & 0.2357 \\
\hline & $40 \mathrm{C} 2$ & 1.6459 & 0.0011 & -0.6150 \\
\hline Logarithmic & $40 \mathrm{C} 3$ & 1.0548 & 0.0020 & -0.0632 \\
\hline & $40 \mathrm{C} 4$ & 0.9617 & 0.0022 & 0.0301 \\
\hline & $50 \mathrm{C} 1$ & 0.7295 & 0.0096 & 0.2687 \\
\hline & $50 \mathrm{C} 2$ & 0.8152 & 0.0066 & 0.1799 \\
\hline & $50 \mathrm{C} 3$ & 0.7453 & 0.0080 & 0.2525 \\
\hline & $50 \mathrm{C} 4$ & 0.6977 & 0.0088 & 0.3031 \\
\hline
\end{tabular}



Soybean Seeds (Glycine max (L.) Merrill)

(Table 2 continued)

\begin{tabular}{|c|c|c|c|c|c|c|c|}
\hline Mathematical models & $\mathrm{T}\left({ }^{\circ} \mathrm{C}\right)$ & $a$ & $k_{0}$ & $b$ & $k_{1}$ & & \\
\hline \multirow{13}{*}{ Two terms } & $30 \mathrm{C} 1$ & 0.4797 & 0.0011 & 0.5119 & 0.0032 & & \\
\hline & $30 \mathrm{C} 2$ & 0.5469 & 0.0028 & 0.4680 & 0.0005 & & \\
\hline & $30 \mathrm{C} 3$ & 0.7479 & 0.0011 & 0.2394 & 0.0046 & & \\
\hline & $30 \mathrm{C} 4$ & 0.1055 & 0.0274 & 0.8944 & 0.0012 & & \\
\hline & $40 \mathrm{C} 1$ & 0.4711 & 0.0032 & 0.4711 & 0.0017 & & \\
\hline & $40 \mathrm{C} 2$ & 0.5262 & 0.0022 & 0.5262 & 0.0022 & & \\
\hline & $40 \mathrm{C} 3$ & 0.4979 & 0.0022 & 0.4979 & 0.0022 & & \\
\hline & $40 \mathrm{C} 4$ & 0.4946 & 0.0021 & 0.4947 & 0.0021 & & \\
\hline & $50 \mathrm{C} 1$ & 0.4159 & 0.0009 & 0.5837 & 0.0132 & & \\
\hline & $50 \mathrm{C} 2$ & 0.2654 & 0.1171 & 0.7346 & 0.0027 & & \\
\hline & $50 \mathrm{C} 3$ & 0.4609 & 0.0012 & 0.5388 & 0.0119 & & \\
\hline & $50 \mathrm{C} 4$ & 0.2345 & -0.0005 & 0.7658 & 0.0078 & & \\
\hline & $\mathrm{T}\left({ }^{\circ} \mathrm{C}\right)$ & $a$ & $b$ & & & & \\
\hline \multirow{13}{*}{ Wang and Sing } & $30 \mathrm{C} 1$ & -0.0019 & 0.000001 & & & & \\
\hline & $30 \mathrm{C} 2$ & -0.0015 & 0.000001 & & & & \\
\hline & $30 \mathrm{C} 3$ & -0.0017 & 0.000001 & & & & \\
\hline & $30 \mathrm{C} 4$ & -0.0016 & 0.000001 & & & & \\
\hline & $40 \mathrm{C} 1$ & -0.0026 & 0.000002 & & & & \\
\hline & $40 \mathrm{C} 2$ & -0.0016 & 0.000001 & & & & \\
\hline & $40 \mathrm{C} 3$ & -0.0020 & 0.000001 & & & & \\
\hline & $40 \mathrm{C} 4$ & -0.0020 & 0.000001 & & & & \\
\hline & $50 \mathrm{C} 1$ & -0.0041 & 0.000006 & & & & \\
\hline & $50 \mathrm{C} 2$ & -0.0038 & 0.000005 & & & & \\
\hline & $50 \mathrm{C} 3$ & -0.0039 & 0.000005 & & & & \\
\hline & $50 \mathrm{C} 4$ & -0.0038 & 0.000005 & & & & \\
\hline & $\mathrm{T}\left({ }^{\circ} \mathrm{C}\right)$ & $a$ & $k$ & $b$ & $k_{0}$ & $c$ & $k_{1}$ \\
\hline \multirow{13}{*}{$\begin{array}{l}\text { Henderson and Pabis } \\
\text { modified }\end{array}$} & $30 \mathrm{C} 1$ & 0.0666 & 0.0935 & 1.3390 & 0.0015 & -0.4063 & 0.0010 \\
\hline & $30 \mathrm{C} 2$ & 0.3326 & 0.0012 & 0.3326 & 0.0012 & 0.3326 & 0.0018 \\
\hline & $30 \mathrm{C} 3$ & 2.0046 & 0.0005 & 0.1420 & 0.1295 & -1.1363 & 0.0001 \\
\hline & $30 \mathrm{C} 4$ & -0.2117 & -0.0006 & 1.0375 & 0.0005 & 0.1734 & 0.0127 \\
\hline & $40 \mathrm{C} 1$ & 0.9865 & 0.0017 & -0.2228 & 0.0015 & 0.2362 & 0.0729 \\
\hline & $40 \mathrm{C} 2$ & 0.3474 & 0.0022 & 0.3546 & 0.0022 & 0.3504 & 0.0022 \\
\hline & $40 \mathrm{C} 3$ & 0.3319 & 0.0022 & 0.3319 & 0.0022 & 0.3319 & 0.0022 \\
\hline & $40 \mathrm{C} 4$ & 0.3297 & 0.0020 & 0.3297 & 0.0022 & 0.3297 & 0.0020 \\
\hline & $50 \mathrm{C} 1$ & 0.3338 & 0.1250 & 0.0009 & -0.0092 & 0.6651 & 0.0026 \\
\hline & $50 \mathrm{C} 2$ & -0.0200 & 0.0058 & 0.7287 & 0.0027 & 0.2911 & 0.0257 \\
\hline & $50 \mathrm{C} 3$ & 0.2242 & 0.0006 & 0.2548 & 0.0021 & 0.5207 & 0.0121 \\
\hline & $50 \mathrm{C} 4$ & 0.2008 & -0.0007 & 0.4849 & 0.0092 & 0.3151 & 0.0052 \\
\hline & $\mathrm{T}\left({ }^{\circ} \mathrm{C}\right)$ & $a$ & $k$ & $n$ & $B$ & & \\
\hline \multirow{12}{*}{ Midilli } & $30 \mathrm{C} 1$ & 0.9758 & -0.0009 & 1.0354 & -0.0028 & & \\
\hline & $30 \mathrm{C} 2$ & 1.0127 & 0.0010 & 1.1488 & 0.0004 & & \\
\hline & $30 \mathrm{C} 3$ & 0.9999 & 0.0660 & 0.2053 & -0.0006 & & \\
\hline & $30 \mathrm{C} 4$ & 1.0000 & 0.0377 & 0.3303 & -0.0005 & & \\
\hline & $40 \mathrm{C} 1$ & 1.0062 & 0.1303 & 0.1769 & -0.0007 & & \\
\hline & $40 \mathrm{C} 2$ & 1.0273 & 0.0008 & 1.1426 & -0.0001 & & \\
\hline & $40 \mathrm{C} 3$ & 0.9990 & 0.0066 & 0.7430 & -0.0003 & & \\
\hline & $40 \mathrm{C} 4$ & 0.9989 & 0.0060 & 0.7790 & -0.0002 & & \\
\hline & $50 \mathrm{C} 1$ & 0.9999 & 0.0367 & 0.6366 & 0.0002 & & \\
\hline & $50 \mathrm{C} 2$ & 0.9997 & 0.0257 & 0.6688 & -0.0003 & & \\
\hline & $50 \mathrm{C} 3$ & 0.9999 & 0.0256 & 0.6875 & 0.0001 & & \\
\hline & $50 \mathrm{C} 4$ & 1.0001 & 0.0100 & 0.8919 & 0.0004 & & \\
\hline
\end{tabular}


(Table 2 continued)

\begin{tabular}{lllll}
\hline Mathematical models & $\mathrm{T}\left({ }^{\circ} \mathrm{C}\right)$ & $a$ & $k$ & $b$ \\
\hline $30 \mathrm{C} 1$ & 0.0665 & 0.0718 & 0.0259 \\
& $30 \mathrm{C} 2$ & 0.6171 & 0.0024 & 0.1824 \\
$30 \mathrm{C} 3$ & 0.0919 & 0.0839 & 0.0169 \\
$30 \mathrm{C} 4$ & 0.1067 & 0.0272 & 0.0452 \\
& $40 \mathrm{C} 1$ & 0.2367 & 0.0740 & 0.0245 \\
Diffusion approximation & $40 \mathrm{C} 2$ & -0.2218 & 0.0688 & 0.0399 \\
$40 \mathrm{C} 3$ & 0.0164 & 0.0587 & 0.0373 \\
$40 \mathrm{C} 4$ & 0.0402 & 0.1059 & 0.0191 \\
$50 \mathrm{C} 1$ & 0.5876 & 0.0131 & 0.0716 \\
$50 \mathrm{C} 2$ & 0.2654 & 0.0788 & 0.0355 \\
$50 \mathrm{C} 3$ & 0.5413 & 0.0119 & 0.1032 \\
$50 \mathrm{C} 4$ & 0.7721 & 0.0077 & -0.0741 \\
\hline
\end{tabular}

Table 3 Coefficient of determination $\left(R^{2}\right)$, mean relative error $(P)$, estimated values of average error (SE) drying of soybean seeds due to different temperatures.

\begin{tabular}{|c|c|c|c|c|c|c|c|c|c|c|c|c|}
\hline \multirow{3}{*}{ Mathematical models } & \multicolumn{12}{|c|}{$R^{2}$ (determination coefficient) } \\
\hline & \multicolumn{4}{|c|}{$30^{\circ} \mathrm{C}$} & \multicolumn{4}{|c|}{$40{ }^{\circ} \mathrm{C}$} & \multicolumn{4}{|c|}{$50{ }^{\circ} \mathrm{C}$} \\
\hline & $\mathrm{C} 1$ & $\mathrm{C} 2$ & $\mathrm{C} 3$ & $\mathrm{C} 4$ & $\mathrm{C} 1$ & $\mathrm{C} 2$ & $\mathrm{C} 3$ & $\mathrm{C} 4$ & $\mathrm{C} 1$ & $\mathrm{C} 2$ & $\mathrm{C} 3$ & $\mathrm{C} 4$ \\
\hline Newton & 0.99 & 0.99 & 0.98 & 0.98 & 0.97 & 0.98 & 0.99 & 0.99 & 0.95 & 0.98 & 0.96 & 0.94 \\
\hline Page & 0.99 & 0.99 & 0.99 & 0.99 & 0.99 & 0.99 & 0.99 & 0.99 & 0.99 & 0.99 & 0.99 & 0.99 \\
\hline Henderson and Pabis & 0.99 & 0.99 & 0.99 & 0.98 & 0.97 & 0.98 & 0.99 & 0.99 & 0.95 & 0.98 & 0.97 & 0.95 \\
\hline Logarithmic & 0.99 & 0.99 & 0.99 & 0.99 & 0.99 & 0.99 & 0.99 & 0.99 & 0.99 & 0.99 & 0.99 & 0.99 \\
\hline Two terms & 0.99 & 0.99 & 0.99 & 0.99 & 0.97 & 0.98 & 0.99 & 0.99 & 0.99 & 0.99 & 0.99 & 0.99 \\
\hline Wang and Sing & 0.99 & 0.99 & 0.99 & 0.98 & 0.97 & 0.99 & 0.99 & 0.99 & 0.98 & 0.98 & 0.98 & 0.98 \\
\hline Henderson and Pabis modified & 0.99 & 0.99 & 0.99 & 0.99 & 0.99 & 0.98 & 0.99 & 0.99 & 0.99 & 0.99 & 0.99 & 0.99 \\
\hline Midilli & 0.99 & 0.99 & 0.99 & 0.99 & 0.99 & 0.99 & 0.99 & 0.99 & 0.99 & 0.99 & 0.99 & 0.99 \\
\hline Diffusion approximation & 0.99 & 0.99 & 0.99 & 0.99 & 0.99 & 0.99 & 0.99 & 0.99 & 0.99 & 0.99 & 0.99 & 0.99 \\
\hline \multirow{2}{*}{ Mathematical models } & \multicolumn{12}{|c|}{$P$ (mean relative error values) } \\
\hline & $\overline{\mathrm{C} 1}$ & $\mathrm{C} 2$ & $\mathrm{C} 3$ & $\mathrm{C} 4$ & $\mathrm{C} 1$ & $\mathrm{C} 2$ & C3 & $\mathrm{C} 4$ & $\mathrm{C} 1$ & $\mathrm{C} 2$ & $\mathrm{C} 3$ & $\mathrm{C} 4$ \\
\hline Newton & 8.97 & 0.67 & 15.5 & 17.8 & 3.01 & 6.79 & 0.14 & 0.38 & 1.33 & 1.59 & 2.78 & 9.89 \\
\hline Page & 2.30 & 4.43 & 2.20 & 1.10 & 0.01 & 12.3 & 0.69 & 0.38 & 0.63 & 0.36 & 0.73 & 1.61 \\
\hline Henderson and Pabis & 1.64 & 1.66 & 1.52 & 1.57 & 11.4 & 16.3 & 1.09 & 0.52 & 44.1 & 28.1 & 33.9 & 32.3 \\
\hline Logarithmic & 14.6 & 6.02 & 0.17 & 0.18 & 24.2 & 16.4 & 1.15 & 0.54 & 0.01 & 0.00 & 0.01 & 0.66 \\
\hline Two terms & 0.05 & 5.91 & 0.81 & 0.24 & 1.03 & 0.33 & 1.74 & 0.91 & 0.04 & 1.24 & 0.20 & 0.32 \\
\hline Wang and Sing & 10.1 & 7.87 & 12.3 & 8.90 & 2.03 & 16.4 & 1.17 & 1.01 & 35.3 & 27.2 & 29.3 & 22.4 \\
\hline Henderson and Pabis modified & 1.18 & 6.28 & 1.64 & 0.55 & 2.31 & 13.9 & 3.04 & 2.15 & 0.07 & 0.66 & 0.19 & 0.71 \\
\hline Midilli & 8.86 & 4.71 & 0.00 & 0.03 & 21.7 & 24.3 & 3.52 & 5.66 & 0.03 & 0.10 & 0.02 & 90.0 \\
\hline Diffusion approximation & 0.55 & 7.24 & 0.46 & 0.23 & 33.9 & 15.7 & 8.34 & 8.03 & 0.17 & 1.21 & 0.08 & 0.14 \\
\hline \multirow{2}{*}{ Mathematical models } & \multicolumn{12}{|c|}{$S E$ (estimated values of average error) } \\
\hline & $\mathrm{C} 1$ & $\mathrm{C} 2$ & $\mathrm{C} 3$ & $\mathrm{C} 4$ & $\mathrm{C} 1$ & $\mathrm{C} 2$ & $\mathrm{C} 3$ & $\mathrm{C} 4$ & $\mathrm{C} 1$ & $\mathrm{C} 2$ & $\mathrm{C} 3$ & $\mathrm{C} 4$ \\
\hline Newton & 0.02 & 0.02 & 0.03 & 0.03 & 0.06 & 0.05 & 0.02 & 0.02 & 0.09 & 0.05 & 0.07 & 0.09 \\
\hline Page & 0.01 & 0.03 & 0.02 & 0.01 & 0.02 & 0.03 & 0.02 & 0.03 & 0.01 & 0.02 & 0.01 & 0.02 \\
\hline Henderson and Pabis & 0.02 & 0.03 & 0.03 & 0.03 & 0.06 & 0.04 & 0.02 & 0.03 & 0.10 & 0.06 & 0.08 & 0.09 \\
\hline Logarithmic & 0.02 & 0.02 & 0.02 & 0.02 & 0.04 & 0.03 & 0.02 & 0.03 & 0.01 & 0.03 & 0.01 & 0.01 \\
\hline Two terms & 0.02 & 0.03 & 0.03 & 0.02 & 0.08 & 0.06 & 0.03 & 0.04 & 0.02 & 0.04 & 0.01 & 0.01 \\
\hline Wang and Sing & 0.02 & 0.02 & 0.03 & 0.84 & 0.06 & 0.03 & 0.02 & 0.03 & 0.06 & 0.05 & 0.05 & 0.04 \\
\hline Henderson and Pabis modified & 0.02 & 0.06 & 0.02 & 0.02 & 0.02 & 0.09 & 0.04 & 0.06 & 0.01 & 0.04 & 0.01 & 0.01 \\
\hline Midilli & 0.03 & 0.02 & 0.02 & 0.02 & 0.05 & 0.03 & 0.02 & 0.04 & 0.01 & 0.04 & 0.01 & 0.11 \\
\hline Diffusion approximation & 0.01 & 0.03 & 0.01 & 0.01 & 0.01 & 0.01 & 0.02 & 0.03 & 0.01 & 0.02 & 0.01 & 0.01 \\
\hline
\end{tabular}


(Table 3 continued)

\begin{tabular}{|c|c|c|c|c|c|c|c|c|c|c|c|c|}
\hline \multirow{3}{*}{ Mathematical models } & \multicolumn{12}{|c|}{ Residual distribution } \\
\hline & \multicolumn{5}{|c|}{$30^{\circ} \mathrm{C}$} & \multicolumn{3}{|c|}{$40^{\circ} \mathrm{C}$} & \multicolumn{4}{|c|}{$50^{\circ} \mathrm{C}$} \\
\hline & $\mathrm{C} 1$ & $\mathrm{C} 2$ & $\mathrm{C} 3$ & $\mathrm{C} 4$ & $\mathrm{C} 1$ & $\mathrm{C} 2$ & $\mathrm{C} 3$ & $\mathrm{C} 4$ & $\mathrm{C} 1$ & $\mathrm{C} 2$ & $\mathrm{C} 3$ & $\mathrm{C} 4$ \\
\hline Newton & A & A & A & A & $\mathrm{T}$ & $\mathrm{T}$ & A & A & $\mathrm{T}$ & $\mathrm{A}$ & $\mathrm{T}$ & $\mathrm{T}$ \\
\hline Page & A & A & A & $\mathrm{A}$ & A & $\mathrm{T}$ & A & A & $\mathrm{T}$ & A & $\mathrm{T}$ & $\mathrm{T}$ \\
\hline Henderson and Pabis & A & A & A & A & $\mathrm{T}$ & $\mathrm{T}$ & A & A & $\mathrm{T}$ & A & $\mathrm{T}$ & $\mathrm{T}$ \\
\hline Logarithmic & A & A & A & $\mathrm{A}$ & A & $\mathrm{T}$ & A & A & $\mathrm{A}$ & $\mathrm{A}$ & $\mathrm{T}$ & $\mathrm{T}$ \\
\hline Two terms & A & A & A & $\mathrm{A}$ & $\mathrm{T}$ & $\mathrm{T}$ & A & A & $\mathrm{A}$ & $\mathrm{T}$ & A & $\mathrm{T}$ \\
\hline Wang and Sing & $\mathrm{A}$ & A & $\mathrm{A}$ & $\mathrm{A}$ & A & $\mathrm{T}$ & A & A & $\mathrm{A}$ & $\mathrm{A}$ & A & $\mathrm{A}$ \\
\hline Henderson and Pabis modified & A & A & A & A & A & $\mathrm{T}$ & A & A & $\mathrm{A}$ & $\mathrm{A}$ & A & $\mathrm{T}$ \\
\hline Midilli & A & $\mathrm{T}$ & A & $\mathrm{A}$ & $\mathrm{T}$ & $\mathrm{T}$ & A & A & $\mathrm{A}$ & $\mathrm{A}$ & A & $\mathrm{A}$ \\
\hline Diffusion approximation & A & A & A & A & A & A & A & A & A & $\mathrm{T}$ & A & A \\
\hline
\end{tabular}

A-aleatory; T-tendentious.

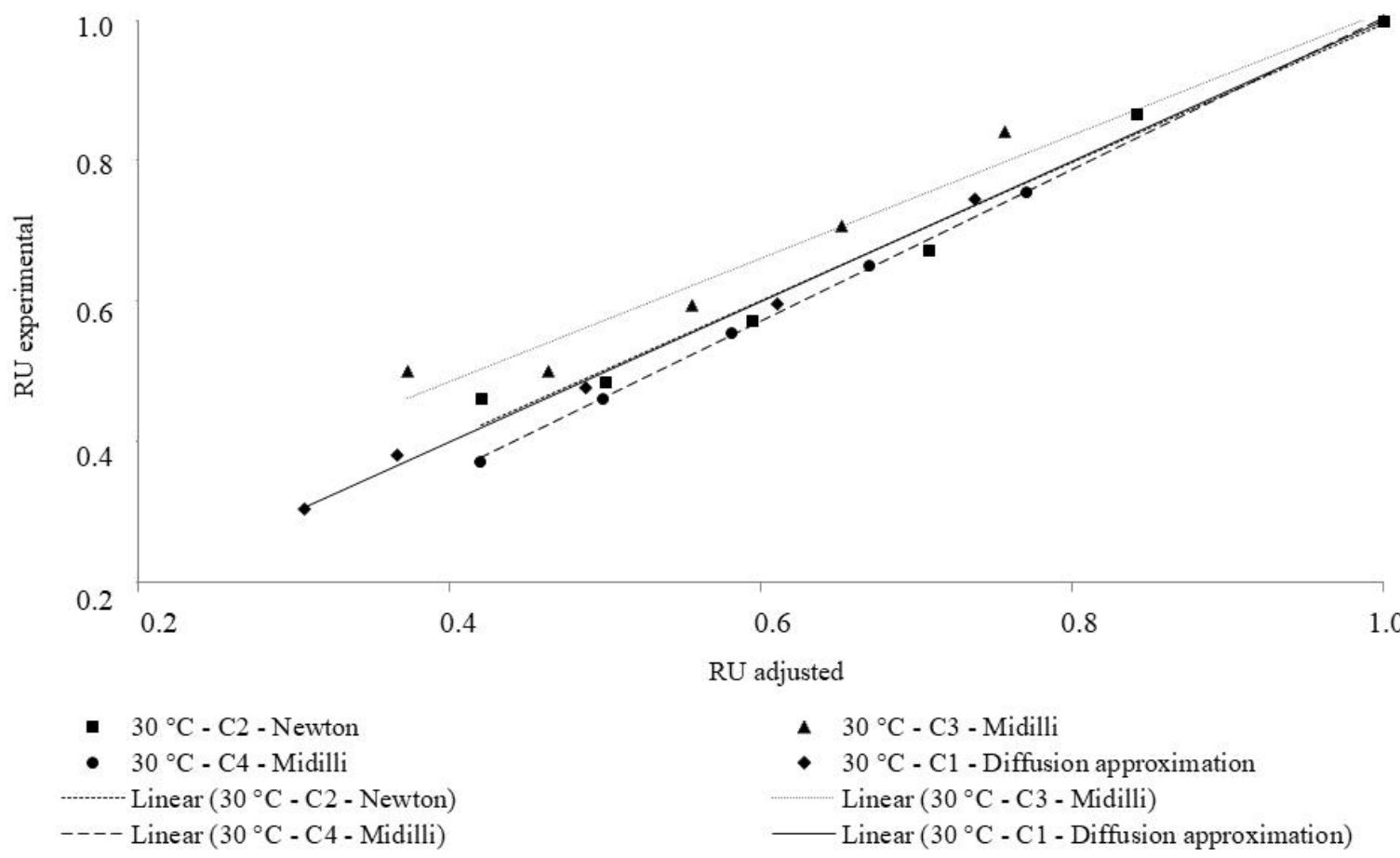

Fig. 5 Experimental and adjusted moisture ratio at $30{ }^{\circ} \mathrm{C}$ in the drying, calculated by the models of diffusion approximation (cell C1), Newton (cell C2) and Midilli (cells C3 and C4).

ranged from $26{ }^{\circ} \mathrm{C}$ to $32{ }^{\circ} \mathrm{C}$ and the relative humidity of the exhaust air ranged from $73 \%$ to $59 \%$.

The increase in the temperature of the drying air showed an increase in the amounts of exudates released in the solution due to higher damage to the grain integuments (Table 5). Seeds that presented values of electrical conductivity higher than 80 $\mu \mathrm{S} / \mathrm{cm} / \mathrm{g}$ with water towers of $13 \%$ (w.b.) are considered of low vigor. The electrical conductivity is inversely proportional to the water content of the grains; thus, the amount of leachate in the solution increases the quantity of water in the grains. The results were in agreement with the results mentioned above wherein the highest values of electrical conductivity were observed in the upper sampling points, where there was a greater reduction of grain water content, independent of the cells [15].

Table 5 shows that the lower sampling point of the 


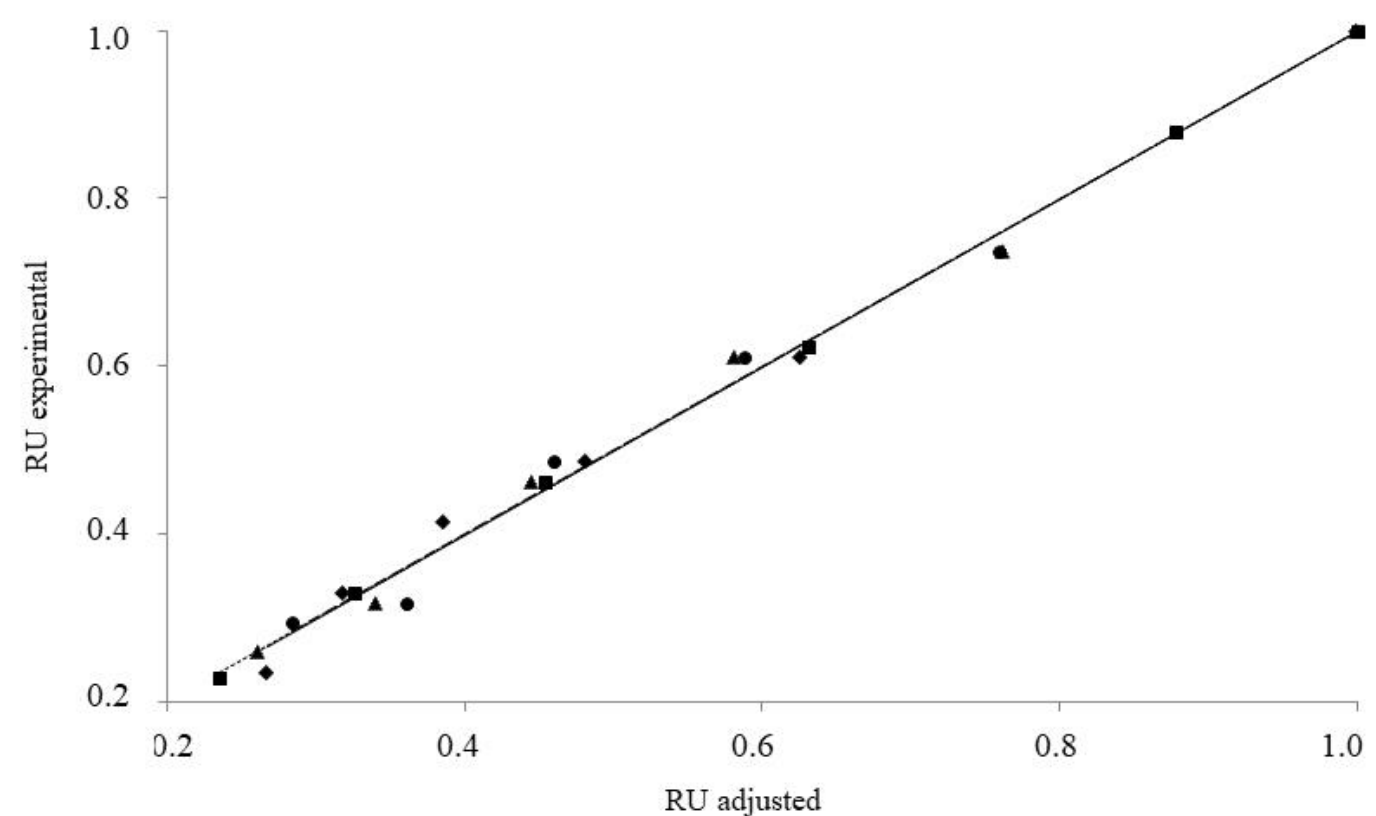

- $40^{\circ} \mathrm{C}-\mathrm{C} 1$ - Page

a $40{ }^{\circ} \mathrm{C}-\mathrm{C} 3-$ Page

Linear $\left(40^{\circ} \mathrm{C}-\mathrm{C} 1\right.$ - Page $)$

Linear $\left(40^{\circ} \mathrm{C}-\mathrm{C} 3\right.$ - Page $)$
- $40{ }^{\circ} \mathrm{C}-\mathrm{C} 2-$ Diffusion approximation

- $40^{\circ} \mathrm{C}-\mathrm{C} 4$ - Page

- Linear $\left(40^{\circ} \mathrm{C}-\mathrm{C} 2\right.$ - Diffusion approximation)

--- Linear $\left(40^{\circ} \mathrm{C}\right.$ - $\mathrm{C} 4$ - Page $)$

Fig. 6 Experimental and adjusted the moisture ratio at $40{ }^{\circ} \mathrm{C}$ in the drying, calculated by the models of diffusion approximation (cell C2), Page (cells $\mathrm{C} 1, \mathrm{C} 3$ and $\mathrm{C} 4$ ).

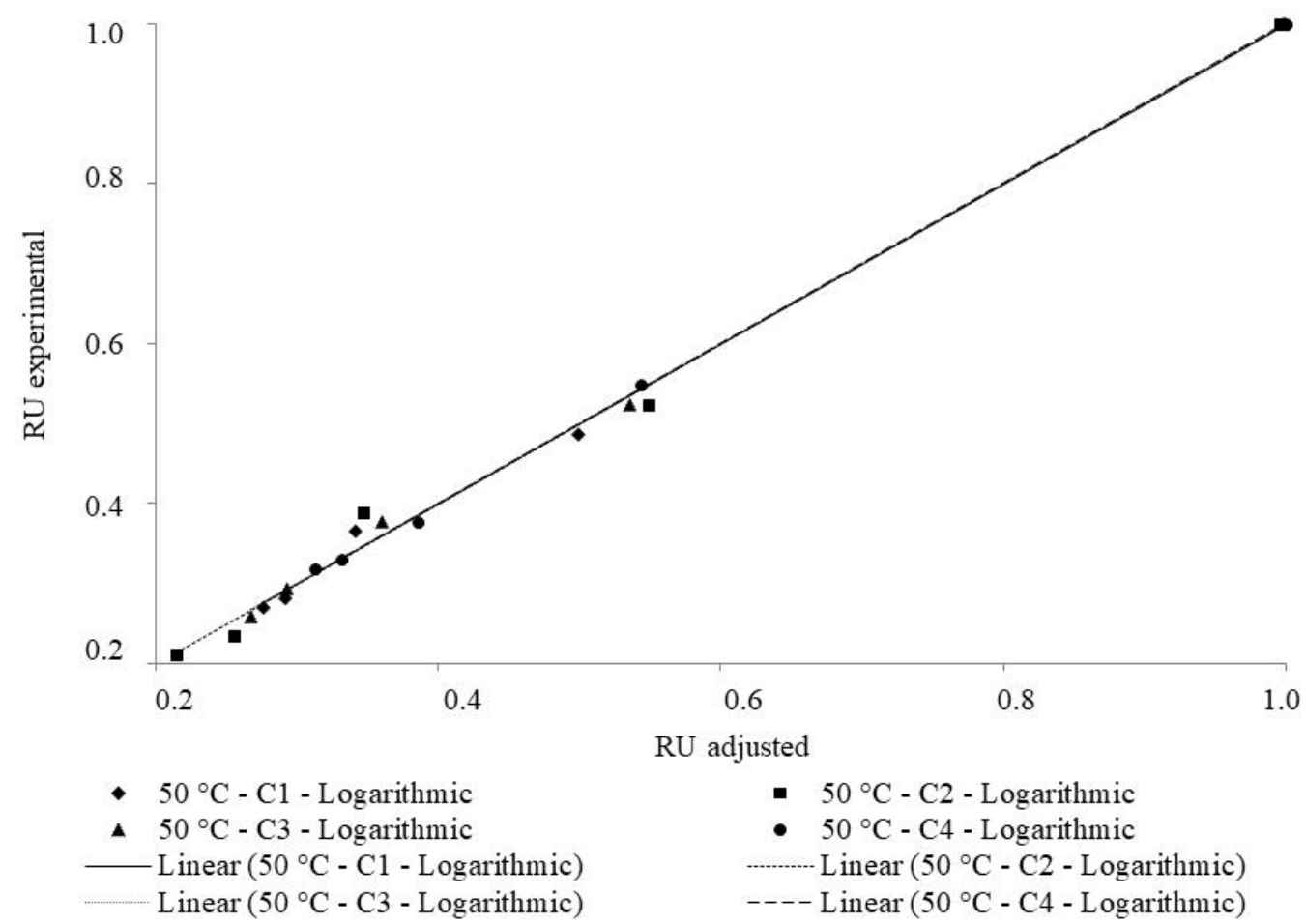

Fig. 7 Experimental and adjusted the moisture ratio at $50^{\circ} \mathrm{C}$ in the drying, calculated by the model Logarithmic (cells $\mathrm{C} 1$, $\mathrm{C2}, \mathrm{C3}$ and C4). 
drying cells, regardless of the air temperature, showed no difference in the evaluation of the electrical conductivity as compared with the other cells. For the mean sampling point, the electrical conductivity was higher in dry grains in cell 1 at $50{ }^{\circ} \mathrm{C}$ and cell 2 at $40{ }^{\circ} \mathrm{C}$, whereas for the air temperature at $30{ }^{\circ} \mathrm{C}$ there was no difference in the electrical conductivity values between the cells. At the upper sampling point, the highest values of electrical conductivity for the air temperature of $50{ }^{\circ} \mathrm{C}$ were observed in cell 4 , with no differences between the cells at temperatures of $30^{\circ} \mathrm{C}$ and $40{ }^{\circ} \mathrm{C}$. The electrical conductivity test can promote a stratification of different levels of seed vigor. Increased electrical conductivity results in the disorganization of the cell membranes of the seeds making them more susceptible to physical damage, such as temperature and humidity, allowing the entry of pathogens and affecting the physiological quality [32]. Also the study corroborated the results of previous studies, which reported an increase in electrical conductivity with an increase in the drying air temperature in bean seeds [33].

Table 6 shows that at a drying air temperature of $30{ }^{\circ} \mathrm{C}$, the percentage germination differed in the cells at the lower and upper points, but at the upper point, only cell 1 differed significantly from the others. Drying at $50{ }^{\circ} \mathrm{C}$ resulted in a difference in the percentage of seed germination between the cells at the lower and medium points. However, at $40{ }^{\circ} \mathrm{C}$ there were no significant differences among cells.

Table 4 Monitoring the drying conditions of soybean seeds.

\begin{tabular}{|c|c|c|c|c|c|c|c|c|c|c|}
\hline \multirow{2}{*}{$\begin{array}{l}\mathrm{UR}_{\text {air amb. }} \\
(\%)\end{array}$} & \multirow{2}{*}{$\begin{array}{l}\mathrm{T}_{\text {air amb. }} \\
\left({ }^{\circ} \mathrm{C}\right)\end{array}$} & \multirow{2}{*}{$\begin{array}{l}\mathrm{T}_{\text {air drying }} \\
\left({ }^{\circ} \mathrm{C}\right)\end{array}$} & \multicolumn{2}{|c|}{ 1-central drying chamber } & \multicolumn{2}{|c|}{ 2-center drying chamber } & \multicolumn{4}{|c|}{ 3-center drying chamber 4-center drying chamber } \\
\hline & & & $\begin{array}{l}\mathrm{T}_{\text {air }} / \mathrm{UR}_{\text {air exhaustion }} \\
\left({ }^{\circ} \mathrm{C} / \%\right)\end{array}$ & $\begin{array}{l}\mathrm{T}_{\text {mass seeds }} \\
\left({ }^{\circ} \mathrm{C}\right)\end{array}$ & $\begin{array}{l}\mathrm{T}_{\text {air }} / \mathrm{UR}_{\text {air exhaustion }} \\
\left({ }^{\circ} \mathrm{C} / \%\right)\end{array}$ & $\begin{array}{l}\mathrm{T}_{\text {mass seeds }} \\
\left({ }^{\circ} \mathrm{C}\right)\end{array}$ & $\begin{array}{l}\mathrm{T}_{\text {air }} / \mathrm{UR}_{\text {air exhaustion }} \\
\left({ }^{\circ} \mathrm{C} / \%\right)\end{array}$ & $\begin{array}{l}\mathrm{T}_{\text {mass seeds }} \\
\left({ }^{\circ} \mathrm{C}\right)\end{array}$ & $\begin{array}{l}\mathrm{T}_{\text {air }} / \mathrm{UR}_{\text {air exhaustion }} \\
\left({ }^{\circ} \mathrm{C} / \%\right)\end{array}$ & $\begin{array}{l}\mathrm{T}_{\text {mass seeds }} \\
\left({ }^{\circ} \mathrm{C}\right)\end{array}$ \\
\hline 70.5 & 26.3 & $30 \pm 2$ & $26 / 72$ & 26.9 & $26 / 73$ & 26.3 & $26 / 73$ & 27.1 & $26 / 73$ & 26.9 \\
\hline 58.8 & 28.6 & $40 \pm 2$ & $29 / 67$ & 29.8 & $29 / 66$ & 29.4 & $29 / 66$ & 30.0 & $29 / 66$ & 29.6 \\
\hline 45.5 & 31.2 & $50 \pm 2$ & $32 / 59$ & 33.5 & $32 / 59$ & 33.9 & $32 / 59$ & 32.1 & $32 / 59$ & 31.9 \\
\hline
\end{tabular}

Table 5 Electrical conductivity $(\mu \mathrm{S} / \mathrm{cm} / \mathrm{g})$ of soybean grains after drying, according to the sampling points in the cells and drying air temperatures.

\begin{tabular}{lllllllllllll}
\hline $\mathrm{T}\left({ }^{\circ} \mathrm{C}\right)$ & \multicolumn{3}{c}{ Cell 1} & \multicolumn{3}{c}{ Cell 2 } & \multicolumn{3}{c}{ Cell 3 } & Cell 4 \\
\cline { 2 - 12 } & $\mathrm{L}$ & $\mathrm{M}$ & $\mathrm{U}$ & $\mathrm{L}$ & $\mathrm{M}$ & $\mathrm{U}$ & $\mathrm{L}$ & $\mathrm{M}$ & $\mathrm{U}$ & $\mathrm{L}$ & $\mathrm{M}$ & $\mathrm{U}$ \\
\hline 30 & $71 \mathrm{Aa}$ & $79 \mathrm{Aa}$ & $77 \mathrm{Aa}$ & $61 \mathrm{Aa}$ & $75 \mathrm{Aa}$ & $77 \mathrm{Aa}$ & $66 \mathrm{Aa}$ & $62 \mathrm{Aa}$ & $71 \mathrm{Aa}$ & $71 \mathrm{Aa}$ & $71 \mathrm{Aa}$ & $77 \mathrm{Aa}$ \\
40 & $67 \mathrm{Aa}$ & $73 \mathrm{Aa}$ & $99 \mathrm{Ab}$ & $92 \mathrm{Ba}$ & $102 \mathrm{Ba}$ & $105 \mathrm{Ca}$ & $75 \mathrm{Aa}$ & $85 \mathrm{Aa}$ & $104 \mathrm{Bb}$ & $81 \mathrm{Aa}$ & $81 \mathrm{Aa}$ & $101 \mathrm{Ba}$ \\
50 & $116 \mathrm{Ba}$ & $132 \mathrm{Bb}$ & $95 \mathrm{Aa}$ & $84 \mathrm{Aa}$ & $94 \mathrm{Aa}$ & $101 \mathrm{Ba}$ & $91 \mathrm{Aa}$ & $118 \mathrm{Bb}$ & $113 \mathrm{Ba}$ & $98 \mathrm{Aa}$ & $113 \mathrm{Ba}$ & $140 \mathrm{Cb}$ \\
$\mathrm{IC}$ & $74 \mathrm{Aa}$ & $74 \mathrm{Aa}$ & $74 \mathrm{Aa}$ & $74 \mathrm{Aa}$ & $74 \mathrm{Aa}$ & $74 \mathrm{Aa}$ & $74 \mathrm{Aa}$ & $74 \mathrm{Aa}$ & $74 \mathrm{Aa}$ & $74 \mathrm{Aa}$ & $74 \mathrm{Aa}$ & $74 \mathrm{Aa}$ \\
\hline
\end{tabular}

Means followed by the same lowercase letter in the line do not differ by Tukey's test at 1\%; means followed by the same capital letter in the column do not differ by Tukey's test at $1 \%$.

L: lower; M: medium; U: upper; IC: initial condition; coefficient of variation $=17.01 \%$.

Table 6 Germination (\%) of soybean grains after drying, according to the sampling points in the cells and drying air temperatures.

\begin{tabular}{|c|c|c|c|c|c|c|c|c|c|c|c|c|}
\hline \multirow{2}{*}{$\mathrm{T}\left({ }^{\circ} \mathrm{C}\right)$} & \multicolumn{3}{|c|}{ Cell 1} & \multicolumn{3}{|c|}{ Cell 2} & \multicolumn{3}{|c|}{ Cell 3} & \multicolumn{3}{|c|}{ Cell 4} \\
\hline & $\mathrm{L}$ & $\mathrm{M}$ & $\mathrm{U}$ & $\mathrm{L}$ & $\mathrm{M}$ & $\mathrm{U}$ & $\mathrm{L}$ & $\mathrm{M}$ & $\mathrm{U}$ & $\mathrm{L}$ & $\mathrm{M}$ & $\mathrm{U}$ \\
\hline 30 & $64.00 \mathrm{Bb}$ & $78.50 \mathrm{Aa}$ & $63.50 \mathrm{Bb}$ & $80.50 \mathrm{Aa}$ & $83.00 \mathrm{Aa}$ & $78.00 \mathrm{Aa}$ & $84.00 \mathrm{Aa}$ & $73.50 \mathrm{Aa}$ & $84.50 \mathrm{Aa}$ & $69.50 \mathrm{Ab}$ & $84.50 \mathrm{Aa}$ & $82.50 \mathrm{Ba}$ \\
\hline 40 & $77.50 \mathrm{Ab}$ & $73.00 \mathrm{Ab}$ & $85.00 \mathrm{Aa}$ & $76.50 \mathrm{Aa}$ & $73.00 \mathrm{Ba}$ & $82.50 \mathrm{Aa}$ & $85.50 \mathrm{Aa}$ & $83.00 \mathrm{Aa}$ & $81.00 \mathrm{Aa}$ & $81.50 \mathrm{Aa}$ & $78.00 \mathrm{Aa}$ & $84.50 \mathrm{Aa}$ \\
\hline 50 & $57.00 \mathrm{Ba}$ & $53.00 \mathrm{Ba}$ & $62.50 \mathrm{Ba}$ & $69.00 \mathrm{Aa}$ & $65.50 \mathrm{Ba}$ & $64.00 \mathrm{Ba}$ & $66.00 \mathrm{Ba}$ & $53.50 \mathrm{Bb}$ & $65.50 \mathrm{Ba}$ & $48.00 \mathrm{Bb}$ & $64.00 \mathrm{Ba}$ & $71.50 \mathrm{Ba}$ \\
\hline IC & $78.00 \mathrm{Aa}$ & $78.00 \mathrm{Aa}$ & $78.00 \mathrm{Aa}$ & $78.00 \mathrm{Aa}$ & $78.00 \mathrm{Aa}$ & $78.00 \mathrm{Aa}$ & $78.00 \mathrm{Ba}$ & $78.00 \mathrm{Aa}$ & $78.00 \mathrm{Aa}$ & $78.00 \mathrm{Aa}$ & $78.00 \mathrm{Aa}$ & $78.00 \mathrm{Ba}$ \\
\hline
\end{tabular}

Means followed by the same lowercase letter in the line do not differ by Tukey's test at 1\%; means followed by the same capital letter in the column do not differ by Tukey's test at $1 \%$.

L: lower; M: medium; U: upper; IC: initial condition; coefficient of variation $=9.14 \%$. 
The highest germination value occurred when the grains were dried at a temperature of $45{ }^{\circ} \mathrm{C}$ both in the shade and prototypes of stationary dryers regulated at temperatures of $35 / 45{ }^{\circ} \mathrm{C}$ [4, 34-36]. Regardless of the drying position of the grains in the dryer and the temperature of the drying air used, the percentage of germination of the grains was reduced when they reached the lowest water contents after drying.

\section{Conclusions}

It was concluded that the silo-dryer-aerator attended the drying conditions of soybean seeds, when it presented uniform distribution of the air in the drying equipment, adjustments of the curves of seed water removal, through diffusion approximation models, Newton, Page, Midilli and Logarítmico, maintenance of the quality of soybean seeds in function of the different drying air temperatures.

\section{Acknowledgments}

The authors thank foundation for support to the Development of Teaching, Science and Technology of the State of Mato Grosso do Sul for financial support, Federal University of Mato Grosso do Sul and Federal University of Santa Maria for providing the physical space for this research.

\section{References}

[1] Conab. 2014. "Follow-Up of the Brazilian Harvest: Crop Grain 2013/2014, Second Survey." Conab, Brasília. Accessed March 19, 2014. http://www.conab.gov.br.

[2] Khatchatourian, O. A. 2012. "Experimental Study and Mathematical Model for Soya Bean Drying in Thin Layer." Biosystems Engineering 113 (1): 54-64.

[3] Corrêa, P. C., Goneli, A. L. D., Afonso Júnior, P. C., Oliveira, G. H. H., and Valente, D. S. M. 2010. "Moisture Sorption Isotherms and Isosteric Heat of Sorption of Coffee in Different Processing Levels." International Journal of Food Science and Technology 45 (1): 2016-22.

[4] Niamnuy, C., Nachaisin, M., Poomsa, N., and Devahastin, S. 2012. "Kinetic Modeling of Drying and Conversion/Degradation of Isoflavones during Infrared Drying of Soybean." Food Chemistry 133 (3): 946-52.
[5] Coradi, P. C., Fernandes, C. H. P., Helmich, J. C., and Goneli, A. L. D. 2016. "Effects of Drying Air Temperature and Grain Initial Moisture Content on Soybean Quality (Glycine $\max$ (L.) Merrill)." Agricultural Engineering 36 (5): 866-76.

[6] Rodríguez, J., Melo, E. C., Mulet, A., and Bom, J. 2014. "Management of Surface Drying Temperature to Increase Antioxidant Capacity of Thyme Leaf Extracts (Thymus vulgaris L.)." Drying Technology 32 (16): 1931-41.

[7] Hashemi, G., Mowla, D., and Kazemeini, M. 2009. "Moisture Diffusivity and Shrinkage of Broad Beans during Bulk drying in an Inert Medium Fluidized Bed Dryer Assisted by Dielectric Heating." Journal Food Engineering 92 (1): 331-8.

[8] Hemis, M., Choudhary, R., and Watson, D. G. 2012. "A Coupled Mathematical Model for Simultaneous Microwave and Convective Drying of Wheat Seeds." Biosystems Engineering 112 (3): 202-9.

[9] Defendi, R. O., Nicolin, D. J., Paraíso, P. R., and Jorge, L. M. D. M. 2016. "Assessment of the Initial Moisture Content on Soybean Drying Kinetics and Transport Properties." Drying Technology 34 (3): 360-71.

[10] Sivakumar, R., Saravanan, R., Elaya, P. A., and Iniyan, S. 2016. "Fluidized Bed Drying of Some Agro Products-A Review." Renewable and Sustainable Energy Reviews 61 (1): 280-301.

[11] Queiroz, D. M., Corrêa, P. C., and Souza, C. M. A. 1999. "SIMSEC-A Program for Drying Simulation." In Proceeding of the Brazilian Post-Harvest Conference, 248.

[12] Goneli, A. L. D., Corrêa, P. C., Magalhães, F. E. A., and Baptestini, F. M. 2011. "Volumetric Shrinkage and Castor Bean Shape during Drying." Acta Scientiarum. Agronomy 33 (1): 1-8.

[13] Coradi, P. C., Fernandes, C. H. P., and Helmich, J. C. 2016b. "Adjustment of Mathematical Models and Quality of Soybean Grains in the Drying with High Temperatures." Brazilian Journal of Agricultural and Environmental Engineering 20 (4): 385-92.

[14] Brasil. 2009. Ministry of Agriculture and Agrarian Reform: Rules for Seed Analysis. Brasília: SNDA/DNDV/CLAV, 22.

[15] Vieira, R. D., and Krzyzanowski, F. C. 1999. "Electrical Conductivity Test." In Seed Vigor: Concepts and Tests. Londrina, PR: ABRATES, 1-26.

[16] Khanchi, A., Jones, C. L., Sharma, B., Huhnke, R. L., Weckler, P., and Maness, N. O. 2013. “An Empirical Model to Predict Infield Thin Layer Drying Rate of Cut Switchgrass." Biomass and Bioenergy 58 (1): 128-35.

[17] Ghazanfari, A., Emani, S., Tabil, N. G., and Panigrahi, S. 2006. "Thin-Layer Drying of Flax Fiber: II. Modeling Drying Process Using Semi-theoretical and Empirical 
Models.” Drying Technology 24 (12): 1637-42.

[18] Ayadi, M., Mabrouk, S. B., and Bellagi, A. 2014. "Kinetic Study of the Convective Drying of Spearmint." Journal of the Saudi Society of Agricultural Sciences 13 (1): 1-7.

[19] Lopes, D. C., Steidle Neto, A. J., and Santiago, J. K. 2014. "Comparison of Equilibrium and Logarithmic Models for Grain Drying." Biosystems Engineering 118 (1): 105-14.

[20] Ozbek, B., and Dadali, G. 2007. "Thin-Layer Drying Characteristics and Modelling of Mint Leaves Undergoing Microwave Treatment." Journal of Food Engineering 83 (4): 541-9.

[21] Soysal, Y., Oztekin, S., and Eren, O. 2006. "Microwave Drying of Parsley: Modelling, Kinetics and Energy Aspects." Biosystems Engineering 93 (4): 403-13.

[22] Steidle Neto, A. J., and Lopes, D. C. 2015. "Thermistor Based System for Grain Aeration Monitoring and Control." Computers and Electronics in Agriculture 116 (1): 45-54.

[23] Ma, H., Zhang, W., and Yang, S. X. 2015. "Systems Modeling and Intelligent Control of Meat Drying Process." In Proceeding of the 10th IEEE System of Systems Engineering Conference, 238-43.

[24] Brooker, D. B., Bakker-Arkema, F. W., and Hall, C. W. 1992. Drying and Storage of Grains and Oilseeds. Westport: The AVI Publishing Company, 450.

[25] Isquierdo, E. P., Borém, F. M., Andrade, E. T., Corrêa, J. L. G., Oliveira, P. D., and Alves, G. E. 2013. "Drying Kinetics and Quality of Natural Coffee." Transactions of the American Society of Agricultural and Biological Engineers 56 (3): 995-1001.

[26] Resende, O., Oliveira, D. E. C., Chaves, T. H., Ferreira, J., and Bessa, V. 2014. "Kinetics and Thermodynamic Properties of the Drying Process of Sorghum (Sorghum bicolor (L.) Moench) Grains." African Journal of Agricultural Research 9 (32): 2453-62.

[27] Jangam, S. V., and Law, C. L. 2010. Drying of Foods, Vegetables and Fruits, 1st ed. Singapore: National
University of Singapore.

[28] Nuthong, P., Achariyaviriya, A., Namsanguan, K., and Achariyaviriya, S. 2011. "Kinetics and Modeling of Whole Longan with Combined Infrared and Hot Air." Journal Food Engineering 102 (3): 233-9.

[29] Babalis, S. J., and Belessiotis, V. G. 2004. "Influence of the Drying Conditions on the Drying Constants and Moisture Diffusivity during the Thin-Layer Drying of Figs." Journal of Food Engineering 65 (1): 449-58.

[30] Corrêa, P. C., Resende, O., and Ribeiro, D. M. 2006. "Drying Characteristics and Kinetics of Coffee Berry." Brazilian Journal of Agroindustrial Products 8 (1): 1-10.

[31] Radünz, L. L., Melo, E. C., Rocha, P. P., Berbert, P. A., and Gracia, L. M. N. 2010. "Study of Essential Oil from Guaco Leaves Submitted to Different Drying Air Temperature." Engineering in Agriculture 18 (1): 241-7.

[32] Vasquez, G. H., Bertolin, D. C., and Spegiorin, C. N. 2011. "Accelerated Aging and Electrical Conductivity Tests to Evaluate the Physiological Quality of Sorghum Seeds (Sorghum bicolor (L.) Moench).” Brazilian Journal of Biosciences 9 (1): 18-24.

[33] Almeida, D. P., Resende, O., Costa, L. M., Mendes, U. C., and Sales, J. F. 2009. "Drying Bean Kinetics of Adzuki (Vigna angularis)." Global Science and Technology 2 (1): 72-83.

[34] Sanjinez-Argandoña, E. J., Branco, I. G., Bittencourt, T. U., and Munhoz, C. L. 2011. "Influence of Temperature and Geometry in the Drying Kinetics of Tomato (Lycopersicum esculentum)." Food Science and Technology 31 (2): 308-12.

[35] Kashaninejad, M., Mortazavi, A., Safekordi, A., and Tabil, L. G. 2007. "Thin-Layer Drying Characteristics and Modeling of Pistachio Nuts." Journal of Food Engineering 78 (1): 98-108.

[36] Siqueira, V. C., Resende, O., and Chaves, T. H. 2012. "Drying Kinetics of Jatropha Seeds." Revista Ceres 59 (2): 171-7. 